\title{
PERFORMANCE OF CONDUCTIVE PRE-PRIMERS APPLIED ON GALVANIZED STEEL SHEETS FOR AUTOMOTIVE BODIES ${ }^{(*)}$
}

\author{
D. Santos ${ }^{(1)()}$, H. Raminhos ${ }^{(1)}$, M. Costa(1), T. Diamantino(1) and F. Goodwin ${ }^{(2)}$
}

Artigo submetido em Maio de 2007 e aceite em Agosto de 2007

\begin{abstract}
The main driving forces concerning the use of pre-primed automotive sheet are corrosion protection increase and cost reduction during vehicle manufacturing. In this work, the behaviour of two conductive primers, codified by 1 and 2 , was studied and compared with that of a conventional electrophoretic primer. Primer 1 is an organic zinc rich silicate with a low thickness (near $4 \mu \mathrm{m}$ ) and primer 2 is a very thin (near $2 \mu \mathrm{m}$ ) water based primer filled with graphite. These primers were applied on electrogalvanized, hot dip galvanized and galvannealed steel sheets.

Formability capabilities of pre-primed galvanized steel sheets were evaluated, through cupping and stone chipping tests, according to EN ISO 1520 and ASTM D3170, respectively. To evaluate corrosion protection, the samples were submitted to a corrosion cyclic test according to VDA procedure 621-415 contained in the SEP 1160. Corrosion mechanisms were studied by scanning electron microscopy (SEM) with X-ray microanalysis by dispersive energy spectrometry (EDS) associated.

Primers 1 and 2 offer cathodic protection when exposed, however by different manners, and allow previous welding works. Primer 1 acts as a zinc rich primer and primer 2 acts as a sealer of metallic zinc coatings, not allowing zinc depletion and delaying the appearance of iron corrosion from the steel substrate. After some exposure time it was possible to see on the surface of the primer 2, zinc corrosion products arising from the pores of the paint coating. Primers 1 and 2 applied with a low thickness, seem to be good alternatives to the conventional electrophoretic primers.
\end{abstract}

Key Words: Automotive, Conductive Pre-Primers, Steel Sheets, Metallic Zinc Coatings

\section{DESEMPENHO DE PRÉ-PRIMÁRIOS CONDUTORES PARA A INDÚSTRIA AUTOMÓVEL APLICADOS SOBRE CHAPA DE AÇO COM REVESTIMENTOS DE ZINCO}

\section{RESUMO}

Os aspectos ligados ao uso na indústria automóvel, de chapa com pré-primário aplicado, visam sobretudo o aumento da protecção anticorrosiva e a redução de custos durante o fabrico de veículos. Neste trabalho, estudou-se o comportamento de dois primários condutores, referenciados por 1 e 2, e comparou-se o mesmo com o de um primário electroforético convencional. O primário 1 é um silicato orgânico rico em zinco com baixa espessura (cerca de $4 \mu \mathrm{m}$ ) e o primário 2 consiste num primário de base aquosa contendo grafite, com espessura muito baixa (cerca de $2 \mu \mathrm{m}$ ). Aplicaram-se estes primários sobre chapas de aço electrozincadas, galvanizadas por imersão a quente e com "gavanneal".

Avaliaram-se as características de formabilidade das chapas de aço com pré-primário aplicado, recorrendo-se a ensaios de embutimento e de resistência à projecção de gravilha, efectuados de acordo com as nomas EN ISO 1520 e ASTM D3170, respectivamente. Por microscopia electrónica de varrimento (SEM) com microanálise de raios X por espectrometria de dispersão de energias (EDS) associada estudaram-se os mecanismos de corrosão.

Os primários 1 e 2 quando expostos, oferecem protecção catódica, embora de modos diferentes, e permitem trabalhos de soldadura prévios. O primário 1 actua como um primário rico em zinco e o primário 2 actua como selante dos revestimentos metálicos de zinco, não permitindo a "exaustão" do zinco e retardando o aparecimento da corrosão do ferro a partir do substrato de aço. Após algum tempo de exposição foi possível observar na superfície do primário 2, produtos de corrosão do zinco que surgiam através dos poros do revestimento por pintura. Os primários 1 e 2 aplicados com uma espessura baixa, parecem ser boas alternativas aos primários electroforéticos convencionais.

Palavras Chave: Automóvel, Pré-Primários Condutores, Chapas de Aço, Revestimentos Metálicos de Zinco

\section{INTRODUCTION}

In the 1960's automotive body corrosion resulting from de-icing salt, used in winter in the heavy snowfall regions of North America and Northern Europe, became a serious economic problem. The Canadian government issued anticorrosion standards for automobiles in 1976 [1], and automobile manufacturers later started providing anti-corrosion guarantees on the automobiles. In recent years, European and some other automobile manufacturers began offering 12-years warranties.

Coatings are used to enhance appearance and assure that functional requirements are met. Electrocoat is a widely used coating technology that has provided excellent levels of performance on industrial metal materials for more than 40 years.

\footnotetext{
(1) INETI, I.P. - Laboratório de Tratamento de Superfícies e Revestimentos, Estrada do Paço do Lumiar, 1649-038 Lisboa, Portugal

(2) ILZRO - International Lead Zinc Research Organization, Inc., 2525 Meridian Parway, Suite 100, Durham, NC 27713 EUA

() A quem a correspondência deve ser dirigida, e-mail:dulcinea.santos@ineti.pt

(") Trabalho apresentado no "SAE World Congress \& Exhibition" , Abril, 2007
} 
In the early 1960's, anodic automobile body primers were commercialized. In 1971, cathodic technology was introduced, and in 1976 cathodic primers for automobiles appeared [2].

Several driving forces have increased the use of preprimed automotive sheet in recent years [3]. High performance and cost reduction during vehicle manufacturing are the main requirements. It will be possible to save costs significantly if the conventional electrophoretic primer can be eliminated or its usage reduced. Introduction of conductive pre-primers in the automotive industry is a significant improvement because they are applied with low thicknesses and enable weldability. Corrosion resistance, forming, welding and adhesive bonding properties are important factors. In this work, the performance of two conductive primers were studied and compared with that of a conventional electrophoretic primer. These primers were applied on zinc coated steel sheets. Three zinc coatings were included: electrogalvanized (pure zinc), hot-dip galvanized and galvanneal.

\section{EXPERIMENTAL}

\subsection{Materials}

$\underline{\text { Substrates }}$

Three metallic zinc coatings applied on steel, were used as substrates: $\mathrm{Zn}$ electrogalvanized, hot-dip galvanized and galvanneal, codified by EG, GI and GA respectively.

\section{Primers}

This study included: two different conductive primers (with different conductive fillers), codified by 1 and 2, and a conventional electrophoretically applied primer system used as baseline, codified by ELPO. Primer 1 was Grancoat ZE, a zinc based conductive primer, applied in the USA. Primer 2 was Granocoat $\mathrm{X}$, a very thin conductive experimental primer containing graphite, applied in Germany.

Previously to the application a primer, all the panels were pre-treated with a new environment-friendly (non-chrome) treatment, codified by Bonderite 1456X.

Panels with two shapes were considered: flat panels and "pie pan" deformed panels.

\subsection{Studies}

\section{Thickness}

The thickness of pre-primed samples was evaluated by two different methods: following the method $6 \mathrm{~A}$ included in the ISO 2808 standard [4] and by scanning electron microscopy (SEM).

Total thickness of primers plus corresponding substrate was measured [4] using an Elcometer 200SP equipment. After that, the primer was removed by pickling and the thickness of the substrates was measured, being the thickness of the primer evaluated by subtraction to the total thickness.

Samples obtained by cross-section of pre-primed flat panels, were observed by SEM and the thickness of substrates and primers was evaluated. A high resolution Philips XL 30 FEG/EDAX NX scanning electron microscope was used.

\section{Formability Capabilities}

\section{Cupping test}

The cupping test was performed according to EN ISO 1520 [5]. Three of each sort of panels (EG, GI and GA), with primers were deformed using the equipment Erichsen model 202. After the panel was firmly fixed in the cupping apparatus $(\sim 10 \mathrm{kN})$, the test was carried out using a mean speed of indentation of about $4.3 \mathrm{~mm} \mathrm{~m}^{-1}$. The test stopped immediately before fracture appeared, in other others until a crack was first observed on the surface of the coating [5].

\section{Stone chipping test}

The stone chipping test was carried out, according to ASTM D3170 [6], in which three panels of each sort of panels (EG, GI and $G A$ ), with primers, were tested.

The panels were chilled to $0^{\circ} \mathrm{C}$ before the test itself. The test lasted for about 15 seconds, using about $550 \mathrm{~mL}$ of gravel, with a maximum projection pressure of about 55 psi.

\section{Corrosion Mechanisms}

Cyclic corrosion test

The pre-primed samples were submitted to a corrosion cycle test according to the VDA-procedure 621-415 [7] contained in the SEP 1160 [8]. The cycle consists of:

- 1 day salt spray test according to DIN 50021-SS (ASTM B117) [9].

- 4 days cyclic humidity, being each daily cycle composed by $3 \mathrm{~h}$ at $40{ }^{\circ} \mathrm{C}$ and $98 \%$ relative humidity and $16 \mathrm{~h}$ at $23{ }^{\circ} \mathrm{C}$ and $50 \%$ relative humidity.

- 2 days ambient climate according to DIN 50014 [10].

Alternatively, the primer 1 was also exposed to a cycle according to SAE J2334 procedure [11], composed by:

In normal working days (during the week):

- 6 hours at $50{ }^{\circ} \mathrm{C}$ and $100 \%$ relative humidity.

- 5 minutes of salt spray (ASTM B117) [9].

- $17 \mathrm{~h} 45 \mathrm{~min}$ at $60^{\circ} \mathrm{C}$ and $50 \%$ relative humidity.

In the weekends and holidays:

- always $60^{\circ} \mathrm{C}$ and $50 \%$ of relative humidity.

For salt spray and humidity exposures the Erichsen 606 and Tabai PR-25SP test chambers were respectively used.

Panels submitted to cupping test, panels submitted to stone chipping test and "pie pan" deformed panels were exposed.

\section{Evaluation of corrosion severity}

During and after cyclic corrosion tests, visual inspections were performed. Blisters found on samples submitted to stone chipping test were classified in accordance with EN ISO 4628 Standard part 2 [12].

\section{Study of corrosion mechanisms by scanning electron} microscopy (SEM)

With the purpose of knowing the corrosion mechanisms, samples were studied by scanning electron microscopy (SEM) with X-ray microanalysis by energy dispersive spectrometry (EDS) associated. This study included unexposed and exposed 
samples. The surface and samples obtained by cross-section were studied. A high resolution Philips XL 30 FEG/EDAX NX scanning electron microscope was used. Before SEM/EDS studies, the samples were coated with a thin gold film.

\section{RESULTS AND DISCUSSION}

Tables 1 to 3 contain the mean thickness values of metallic coatings and primers. For primer 1 , the evaluation of primer thickness from SEM micrographs was not feasible, due to difficult observation of the interface between the primer and the resin used for the preparation of cross section samples (Fig. 1). For the electrophoretic primer, due to its difficult removal by pickling, the individual thickness was measured on SEM micrographs (Fig. 2 and 3).

Table 1

Mean Coating Thickness of Primer 1 Samples

\begin{tabular}{c|c|c}
\hline \multirow{2}{*}{ Sample Type } & \multicolumn{2}{|c}{ Mean Coating Thickness $(\mu \mathrm{m})^{*}$} \\
\cline { 2 - 3 } & Metallic Coating & Primer 1 \\
\hline EG + Primer 1 & 8 & 4 \\
\hline GI + Primer 1 & 11 & 4 \\
\hline GA + Primer 1 & 10 & 2 \\
\hline
\end{tabular}

* From pickling and measurements according to ISO 2808, Method 6A.

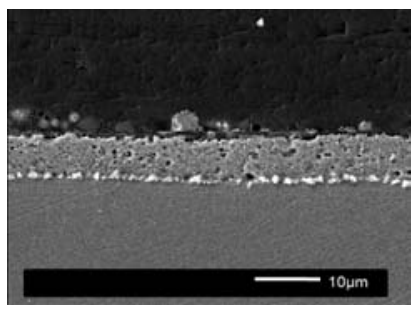

EG

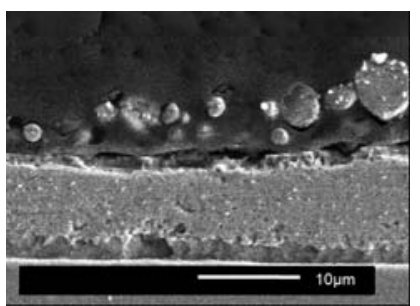

GI

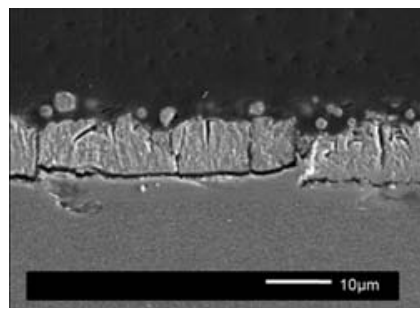

GA

Fig. 1 - Appearance, observed by SEM, of samples obtained by cross section of primer 1 applied on electrogalvanized, hot dip galvanized and galvannealed substrates.

Table 2

Mean Coating Thickness of Primer 2 Samples

\begin{tabular}{c|c|c}
\hline \multirow{2}{*}{ Sample Type } & \multicolumn{2}{|c}{ Mean Coating Thickness $(\mu \mathrm{m})^{\star *}$} \\
\cline { 2 - 3 } & Metallic Coating & Primer 1 \\
\hline EG + Primer 2 & 6 & 2 \\
\hline GI + Primer 2 & 10 & 2 \\
\hline GA + Primer 2 & 9 & 2 \\
\hline
\end{tabular}

** From SEM micrographs of samples obtained by cross section (Fig. 2).

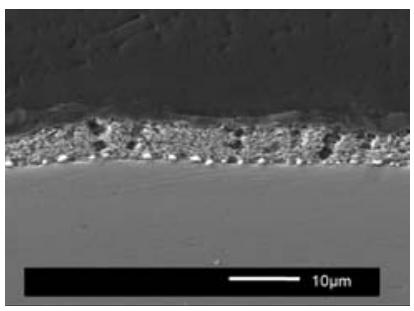

EG

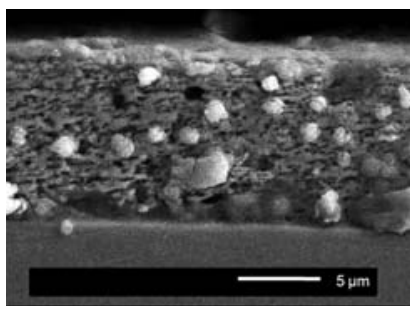

GI

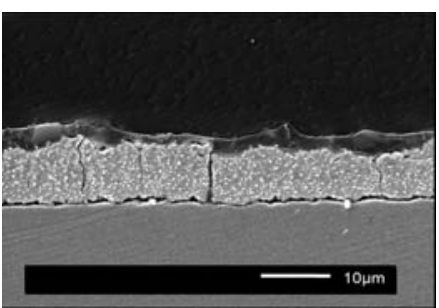

GA

Fig. 2 - Appearance, observed by SEM, of samples obtained by cross section of primer 2 applied on electrogalvanized, hot dip galvanized and galvannealed substrates.

Table 3

Mean Coating Thickness of Electrophoretic Primer System Samples

\begin{tabular}{c|c|c|c}
\hline \multirow{2}{*}{$\begin{array}{c}\text { Sample } \\
\text { Type }\end{array}$} & \multicolumn{3}{|c}{ Mean Coating Thickness $(\mu \mathrm{m})$} \\
\cline { 2 - 4 } & $\begin{array}{c}\text { ISO 2808, } \\
\text { Method 6A }\end{array}$ & \multicolumn{2}{|c}{$\begin{array}{c}\text { SEM micrograph } \\
\text { (Fig) }\end{array}$} \\
\cline { 2 - 4 } & Total & $\begin{array}{c}\text { Metallic } \\
\text { Coating }\end{array}$ & $\begin{array}{c}\text { Electrophoretic } \\
\text { Primer }\end{array}$ \\
\hline EG + ELPO & 33 & 6 & 26 \\
\hline GI + ELPO 35 & 35 & - & - \\
\hline GA + ELPO & 35 & - & - \\
\hline
\end{tabular}

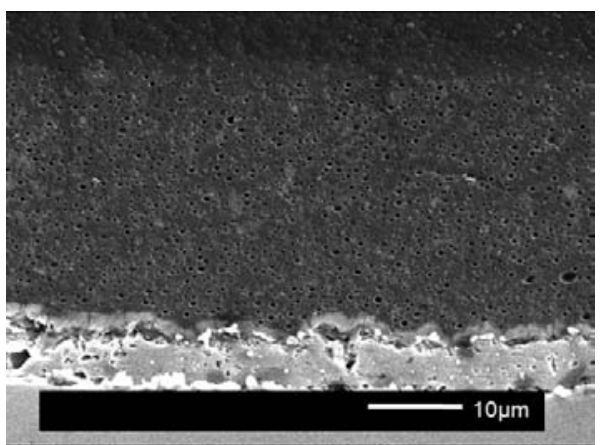

Fig. 3 - Appearance, observed by SEM, of sample obtained by cross section of electrophoretic primer system applied on electrogalvanized substrate.

The results of cupping and stone chipping tests are presented in Tables 4 and 5. Primers 1 and 2 showed formability capabilities similar to that of the electrophoretic primer.

Concerning cupping test, the Erichsen indices (IE) are similar for the three primers and for the three substrates, with difference between mean values less then $2 \mathrm{~mm}$. Only the hot dip galvanized steel coated with the primer 2, with higher depth of indentation, seems to present some better formability. 
However, the minimum depth of indentation at which the coating cracks was high for all of them.

From the results of stone chipping test, it was verified that the three primers present better performance when applied on hot-dip galvanized steel than on electrogalvanized or galvannealed steel. Generally, it was verified similar performance of samples with electrophoretic primer and of samples with primer 2, which is somewhat higher than that of samples with primer 1 with higher number of chips. In spite of the considerable number of chips observed (100-150 [6]), it was verified, that for the three primers and for the three substrates, these chips had small size (diameter: 1-3 $\mathrm{mm}$ [6]) and by SEM/EDS studies performed that they did not reach the steel substrate.

Table 4

Results of Cupping Test

\begin{tabular}{c|c|c|c}
\hline \multirow{2}{*}{ Sample Type } & \multicolumn{3}{|c}{$\mathrm{IE}(\mathrm{mm})$} \\
\cline { 2 - 4 } & Primer 1 & Primer 2 & ELPO \\
\hline EG + Primer & 9.5 & 10.0 & 9.8 \\
\hline GI + Primer & 9.8 & 11.7 & 10.4 \\
\hline GA + Primer & 9.5 & 9.8 & 9.8 \\
\hline
\end{tabular}

Table 5

Results of Stone Chipping Test

\begin{tabular}{c|c|c|c|c|c|c}
\hline \multirow{2}{*}{ Sample Type } & \multicolumn{2}{|c|}{ Primer 1 } & \multicolumn{2}{c|}{ Primer 2} & \multicolumn{2}{c}{ ELPO } \\
\cline { 2 - 7 } of & $\begin{array}{c}\text { No. } \\
\text { chips }\end{array}$ & $\begin{array}{c}\text { Size of } \\
\text { chips } \\
(\mathrm{mm})\end{array}$ & $\begin{array}{c}\text { No. } \\
\text { of } \\
\text { chips }\end{array}$ & $\begin{array}{c}\text { Size of } \\
\text { chips } \\
\text { (mm) }\end{array}$ & $\begin{array}{c}\text { No. } \\
\text { of } \\
\text { chips }\end{array}$ & $\begin{array}{c}\text { Size of } \\
\text { chips } \\
(\mathrm{mm})\end{array}$ \\
\hline EG + Primer & 131 & $1-3$ & 124 & $1-3$ & 115 & $1-3$ \\
\hline GI + Primer & 125 & $1-3$ & 106 & $1-3$ & 102 & $1-3$ \\
\hline GA + Primer & 145 & $1-3$ & 117 & $1-3$ & 110 & $1-3$ \\
\hline
\end{tabular}

Table 6

Results of exposure to 10 corrosion cycles according to the VDA-procedure 621-415 [7], of primer 1 submitted to cupping and "pie pan" deformations

\begin{tabular}{c|l|l|l}
\hline Area & EG + Primer 1 & GI + Primer 1 & GA + Primer 1 \\
\hline $\begin{array}{c}\text { General } \\
\text { overview }\end{array}$ & $\begin{array}{l}\text { Considerable } \\
\text { Zn corrosion }\end{array}$ & $\begin{array}{l}\text { Considerable } \\
\text { Zn corrosion }\end{array}$ & $\begin{array}{l}\text { Moderate Zn } \\
\text { corrosion }\end{array}$ \\
\hline Pie pan & $\begin{array}{l}\text { Considerable } \\
\text { Zn corrosion }\end{array}$ & $\begin{array}{l}\text { Considerable } \\
\text { Zn corrosion }\end{array}$ & $\begin{array}{l}\text { Moderate Zn } \\
\text { corrosion }\end{array}$ \\
\hline $\begin{array}{c}\text { Cupping } \\
\text { area }\end{array}$ & $\begin{array}{l}\text { Zn corrosion } \\
\text { with dripping; } \\
\text { considerable } \\
\text { Fe corrosion }\end{array}$ & $\begin{array}{l}\text { Zn corrosion } \\
\text { with dripping; } \\
\text { moderate Fe } \\
\text { corrosion }\end{array}$ & $\begin{array}{l}\text { Zn corrosion with } \\
\text { dripping; slight } \\
\text { to moderate Fe } \\
\text { corrosion }\end{array}$ \\
\hline
\end{tabular}
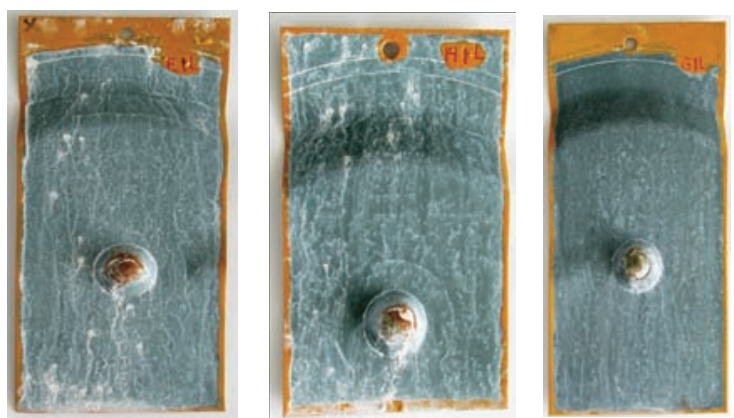

The results of visual inspections performed on the primers applied on the three substrates, with "pie pan" and cupping deformations, submitted to 10 corrosion cycles according to the VDA-procedure 621-415 [7] are presented in Tables 6 to 8. These tables have annexed the corresponding pictures. Results of samples with stone chipping damage, submitted to cyclic corrosion test are presented in the some way in the Tables 9 to 11 .

Table 7

Results of exposure to 10 corrosion cycles according to the VDA-procedure 621-415 [7], of primer 2 submitted to "pie pan" and cupping deformations

\begin{tabular}{c|l|l|l}
\hline Area & EG + Primer 2 & GI + Primer 2 & GA + Primer 2 \\
\hline $\begin{array}{c}\text { General } \\
\text { overview }\end{array}$ & $\begin{array}{l}\text { Considerable } \\
\text { Zn corrosion }\end{array}$ & $\begin{array}{l}\text { Slight Zn } \\
\text { corrosion }\end{array}$ & $\begin{array}{l}\text { Moderate Zn } \\
\text { corrosion }\end{array}$ \\
\hline Pie pan & $\begin{array}{l}\text { Considerable } \\
\text { to severe Zn } \\
\text { corrosion; Fe } \\
\text { corrosion in } \\
\text { the Zn spots }\end{array}$ & $\begin{array}{l}\text { Slight to } \\
\text { moderate Zn } \\
\text { corrosion }\end{array}$ & $\begin{array}{l}\text { Moderate Zn } \\
\text { corrosion }\end{array}$ \\
\hline $\begin{array}{c}\text { Cupping } \\
\text { area }\end{array}$ & $\begin{array}{l}\text { Considerable } \\
\text { Zn corrosion; } \\
\text { severe Fe } \\
\text { corrosion }\end{array}$ & $\begin{array}{l}\text { Considerable } \\
\text { Zn corrosion; } \\
\text { considerable } \\
\text { Fe corrosion }\end{array}$ & $\begin{array}{l}\text { Zn corrosion } \\
\text { to moducts; slight } \\
\text { corrosion }\end{array}$ \\
\hline
\end{tabular}
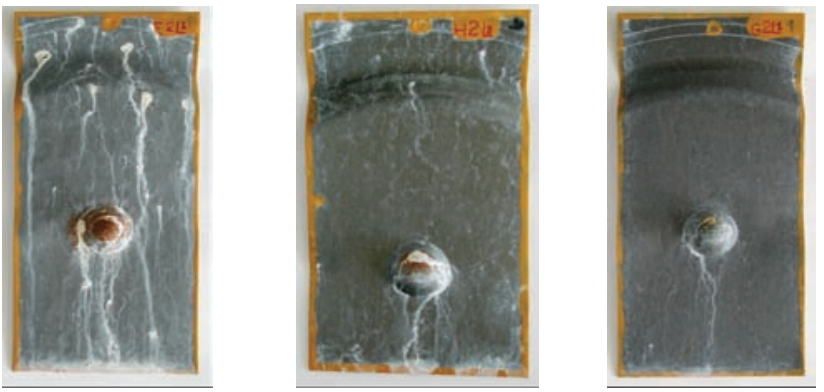

Table 8

Results of exposure to 10 corrosion cycles according to the VDA-procedure 621-415 [7], of electrophoretic primer submitted to cupping and "pie pan" deformations

\begin{tabular}{c|l|l|l}
\hline Area & EG + ELPO & GI + ELPO & GA + ELPO \\
\hline $\begin{array}{c}\text { General } \\
\text { overview }\end{array}$ & No change & No change & No change \\
\hline Pie pan & No change & No change & No change \\
\hline $\begin{array}{c}\text { Cupping } \\
\text { area }\end{array}$ & $\begin{array}{l}\text { Moderate Zn } \\
\text { corrosion in } \\
\text { the rupture } \\
\text { area; } \\
\text { moderate Fe } \\
\text { corrosion; } \\
\text { blisters 4(S3) }\end{array}$ & $\begin{array}{l}\text { Considerable } \\
\text { Zn corrosion; } \\
\text { slight Fe } \\
\text { corrosion; } \\
\text { blisters 5(S3) }\end{array}$ & $\begin{array}{l}\text { Slight Zn } \\
\text { corrosion in } \\
\text { the rupture } \\
\text { area; } \\
\text { considerable } \\
\text { Fe corrosion; } \\
\text { blisters 4(S3) }\end{array}$ \\
\hline
\end{tabular}
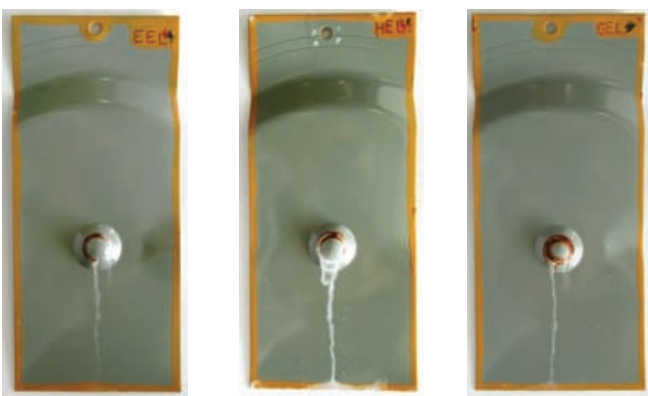
Table 9

Results of exposure to 10 corrosion cycles according to the VDA-procedure 621-415 [7], of primer 1 submitted to stone chipping test

\begin{tabular}{c|l|l|l}
\hline Area & EG + Primer 1 & GI + Primer 1 & GA + Primer 1 \\
\hline $\begin{array}{c}\text { General } \\
\text { overview }\end{array}$ & $\begin{array}{l}\text { Moderate to } \\
\text { considerable } \\
\text { Zn corrosion }\end{array}$ & $\begin{array}{l}\text { Moderate Zn } \\
\text { corrosion }\end{array}$ & $\begin{array}{l}\text { Slight Zn } \\
\text { corrosion }\end{array}$ \\
\hline $\begin{array}{c}\text { Stone } \\
\text { chipping } \\
\text { area }\end{array}$ & $\begin{array}{l}\text { Severe Zn } \\
\text { corrosion; } \\
\text { moderate Fe } \\
\text { corrosion }\end{array}$ & $\begin{array}{l}\text { Severe Zn } \\
\text { corrosion; } \\
\text { moderate Fe } \\
\text { corrosion }\end{array}$ & $\begin{array}{l}\text { Slight Zn } \\
\text { corrosion; } \\
\text { slight Fe } \\
\text { corrosion }\end{array}$ \\
\hline
\end{tabular}
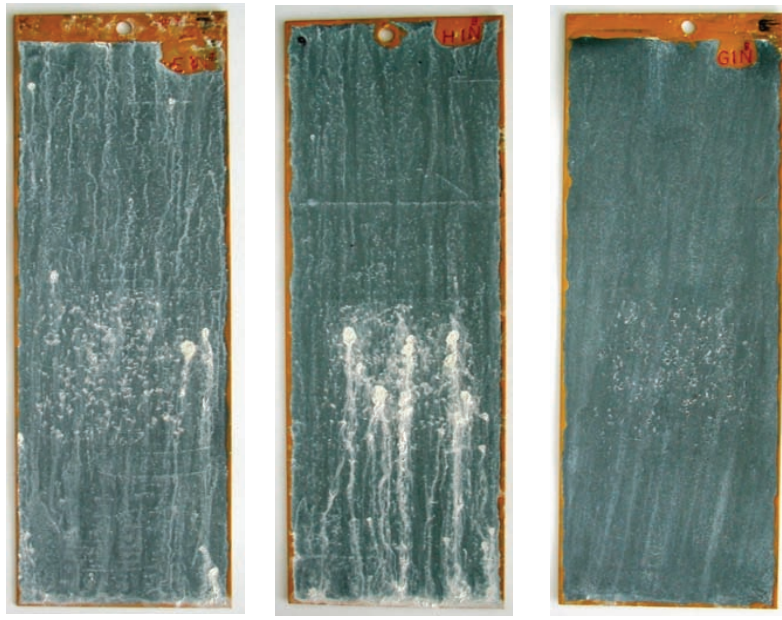

Table 10

Results of exposure to 10 corrosion cycles according to the VDA-procedure 621-415 [7], of primer 2 submitted

to stone chipping test

\begin{tabular}{c|l|l|l}
\hline Area & EG + Primer 2 & GI + Primer 2 & GA + Primer 2 \\
\hline $\begin{array}{c}\text { General } \\
\text { overview }\end{array}$ & $\begin{array}{l}\text { Slight Zn } \\
\text { corrosion }\end{array}$ & $\begin{array}{l}\text { Slight Zn } \\
\text { corrosion }\end{array}$ & $\begin{array}{l}\text { Slight Zn } \\
\text { corrosion }\end{array}$ \\
\hline $\begin{array}{c}\text { Stone } \\
\text { chipping } \\
\text { area }\end{array}$ & $\begin{array}{l}\text { Moderate Zn } \\
\text { corrosion; } \\
\text { slight Fe } \\
\text { corrosion }\end{array}$ & $\begin{array}{l}\text { Moderate Zn } \\
\text { corrosion; } \\
\text { slight Fe } \\
\text { corrosion }\end{array}$ & $\begin{array}{l}\text { Slight Zn } \\
\text { corrosion; } \\
\text { slight Fe } \\
\text { corrosion }\end{array}$ \\
\hline
\end{tabular}
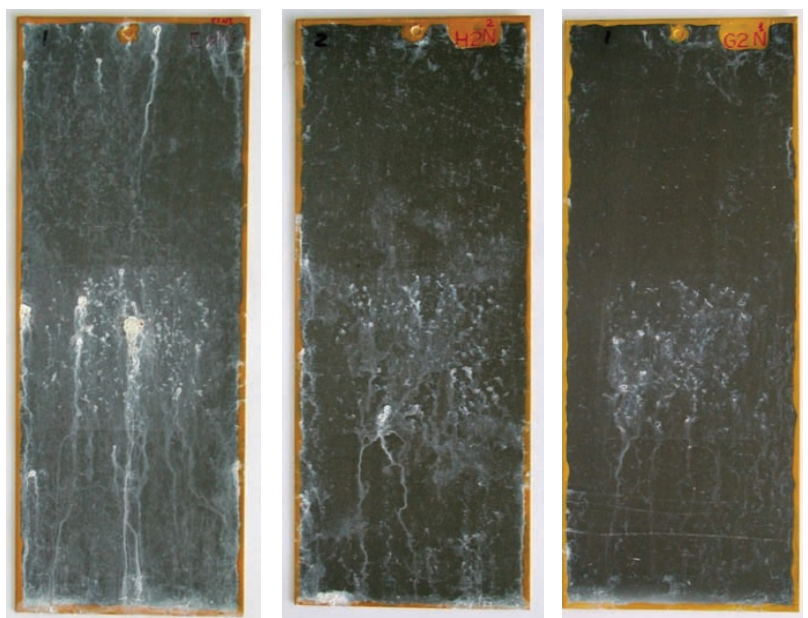

Table 11

Results of exposure to 10 corrosion cycles according to the VDA-procedure 621-415 [7], of electrophoretic primer submitted to stone chipping test

\begin{tabular}{c|l|l|l}
\hline Area & EG + ELPO & GI + ELPO & GA + ELPO \\
\hline $\begin{array}{c}\text { General } \\
\text { overview }\end{array}$ & No change & No change & No change \\
\hline $\begin{array}{c}\text { Stone } \\
\text { chipping } \\
\text { area }\end{array}$ & $\begin{array}{l}\text { Severe Zn } \\
\text { corrosion; } \\
\text { Fe corrosion }\end{array}$ & $\begin{array}{l}\text { Severe Zn } \\
\text { corrosion; } \\
\text { moderate Fe } \\
\text { corrosion }\end{array}$ & $\begin{array}{l}\text { Slight Zn } \\
\text { corrosion; } \\
\text { slight Fe } \\
\text { corrosion }\end{array}$ \\
\hline
\end{tabular}
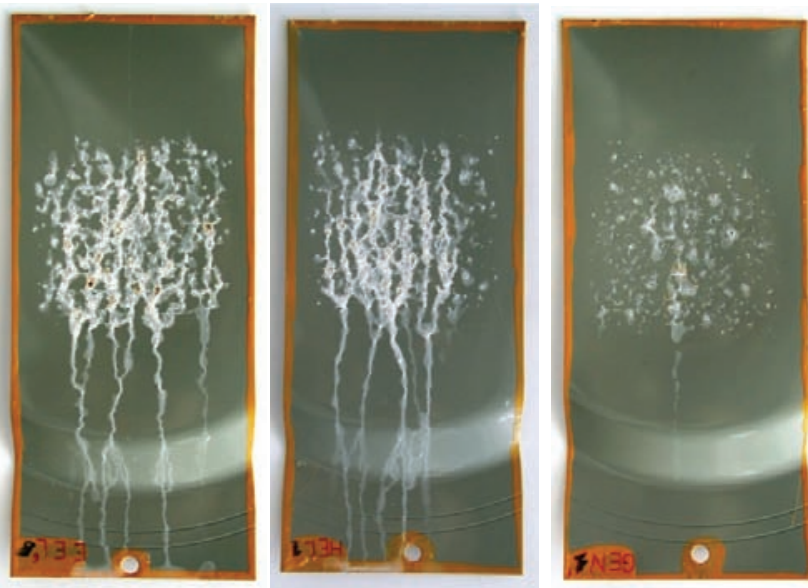

Iron corrosion was not observed on the surface without damage, of the three primers applied on the three substrates. More or less zinc corrosion appeared on the surface of primers 1 and 2. Primer 1 is a zinc rich primer (Fig. 4), and after cyclic corrosion test by SEM, on its surface acicular aggregates and plate-like hexagonal crystals were observed (Fig. 5). Chloride was detected by EDS mainly on the plate-like hexagonal crystals. X-ray diffraction (XRD) studies previously performed on zinc rich primers exposed in salt spray cabinet [13] showed that this crystal correspond to the trigonal compound $\mathrm{Zn}_{5}(\mathrm{OH})_{8} \mathrm{Cl}_{2} \cdot 2 \mathrm{H}_{2} \mathrm{O}$. In these studies previously performed, $\mathrm{Zn}_{5}(\mathrm{OH})_{6}\left(\mathrm{CO}_{3}\right)_{2}$ was identified by XRD as the major component of acicular aggregates in agreement with the results of van Eijnsbergen [14] and others [15]. Hydroxyl chloride, $\mathrm{Zn}_{5}(\mathrm{OH})_{8} \mathrm{Cl}_{2} \cdot 2 \mathrm{H}_{2} \mathrm{O}$, can also be present in acicular aggregates.

The first step in zinc surface degradation seems to be oxidation followed by hydration and fast carbonation as already outlined by several authors [13-14, 16]. In the salt spray cabinet, humidity, temperature and chloride concentration could help to replace basic zinc carbonate and other zinc compounds by increasingly dense plate-like structures of basic zinc chloride (pseudo-hexagonal crystals). It is reasonable to suggest that zinc hydroxychloride hydrate, $\mathrm{Zn}_{5}(\mathrm{OH})_{8} \mathrm{Cl}_{2} \cdot 2 \mathrm{H}_{2} \mathrm{O}$ crystals form from the original zinc hydroxycarbonate. The presence of highly polarizable surface active chloride ions $\left(8.9 \mathrm{~cm}^{3} \mathrm{~mol}^{-1}\right)$ [15] promotes the displacement of carbonate ions (with lower polarizability, $\left(4.1 \mathrm{~cm}^{3} \mathrm{~mol}^{-1}\right)$ from the inner Helmholtz layer, leading to their preferential adsorption on the zinc surface. Evans [15] already proposed a similar zinc oxide hydroxide and carbonate formation. $\mathrm{CO}_{3}{ }^{2-}$ ion has a higher polarizability than that of water $\left(3.7 \mathrm{~cm}^{3} \mathrm{~mol}^{-1}\right)$. 


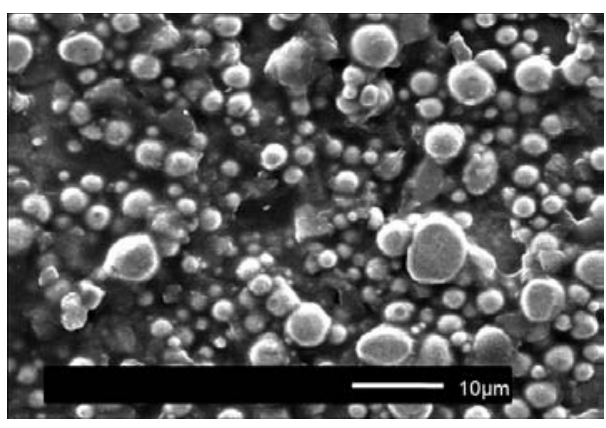

Fig. 4 - Aspect, observed by SEM, of the surface of primer 1 prior to cyclic corrosion test.
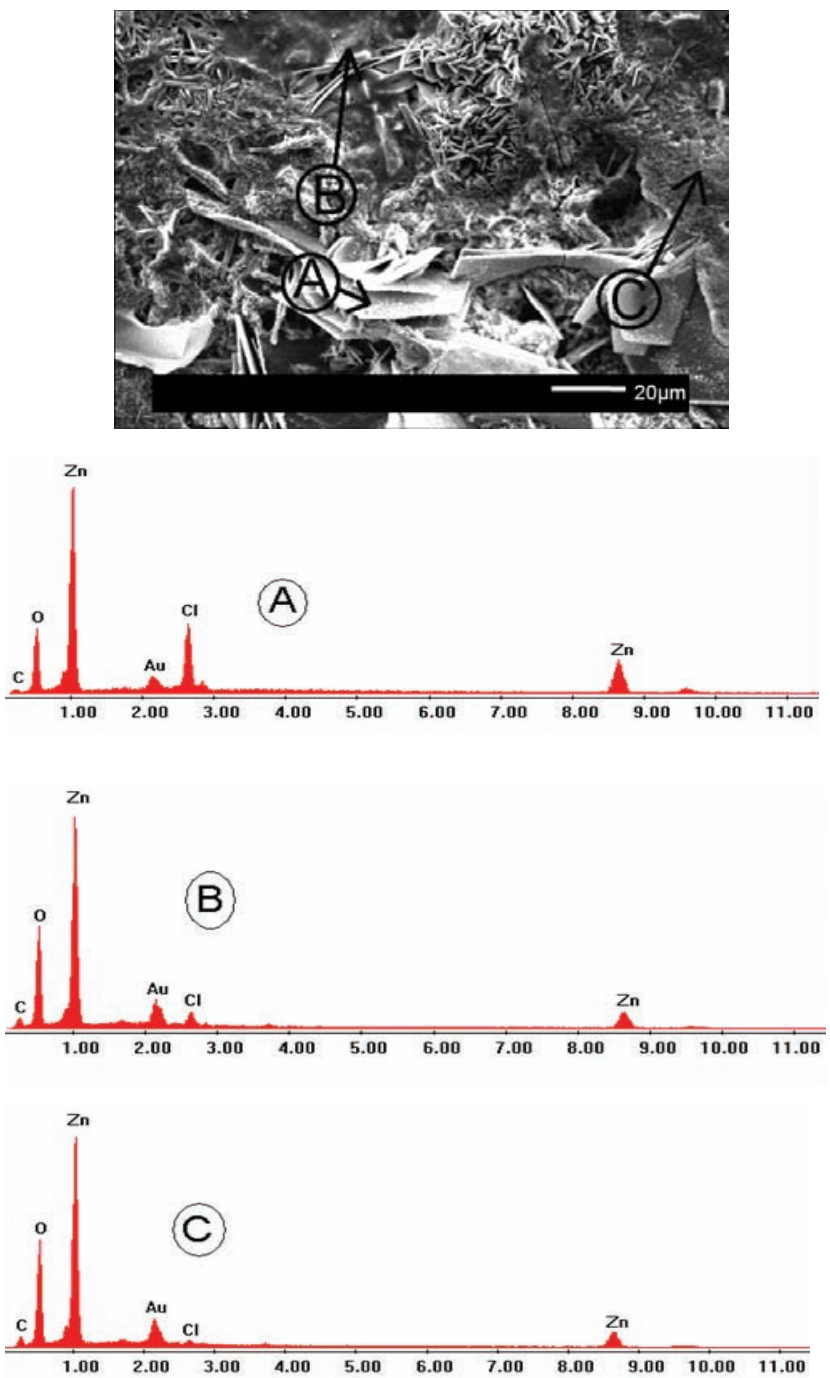

Fig. 5 - Aspect, observed by SEM, of surface of primer 1 applied on hot-dip galvanized steel, after cycle 15 plus 3 weekend cycles according to SAE J2334 procedure [11] and corresponding EDS spectra.

On the surface of unexposed primer 2 , with a very low thickness, it was possible to detected, by EDS, the presence of zinc from the substrate (Fig. 6).

After a short exposure time, zinc corrosion products were visible, which arose through the pores of the coating, as acicular aggregates and plate-like hexagonal crystals (Figure 7).

Regarding the "pie pan deformation", iron corrosion was only observed in the zinc spots of electrogalvanized steel coated with the primer 2 .
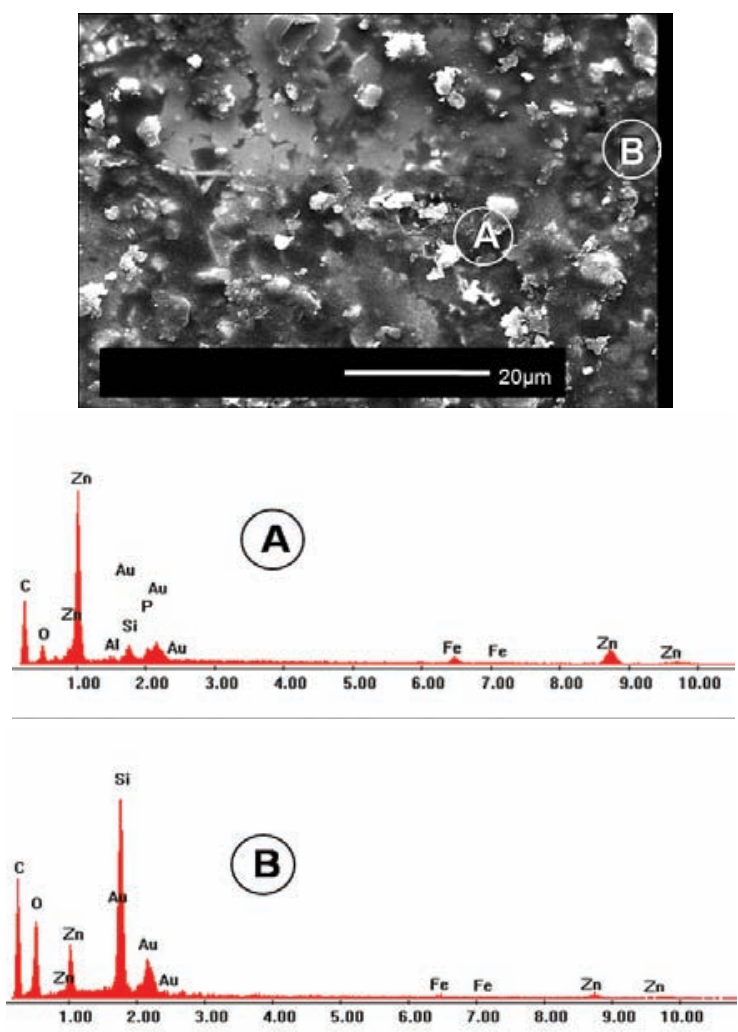

Fig. 6 - Aspect, observed by SEM, of surface of primer 2 without exposure and corresponding EDS spectra.
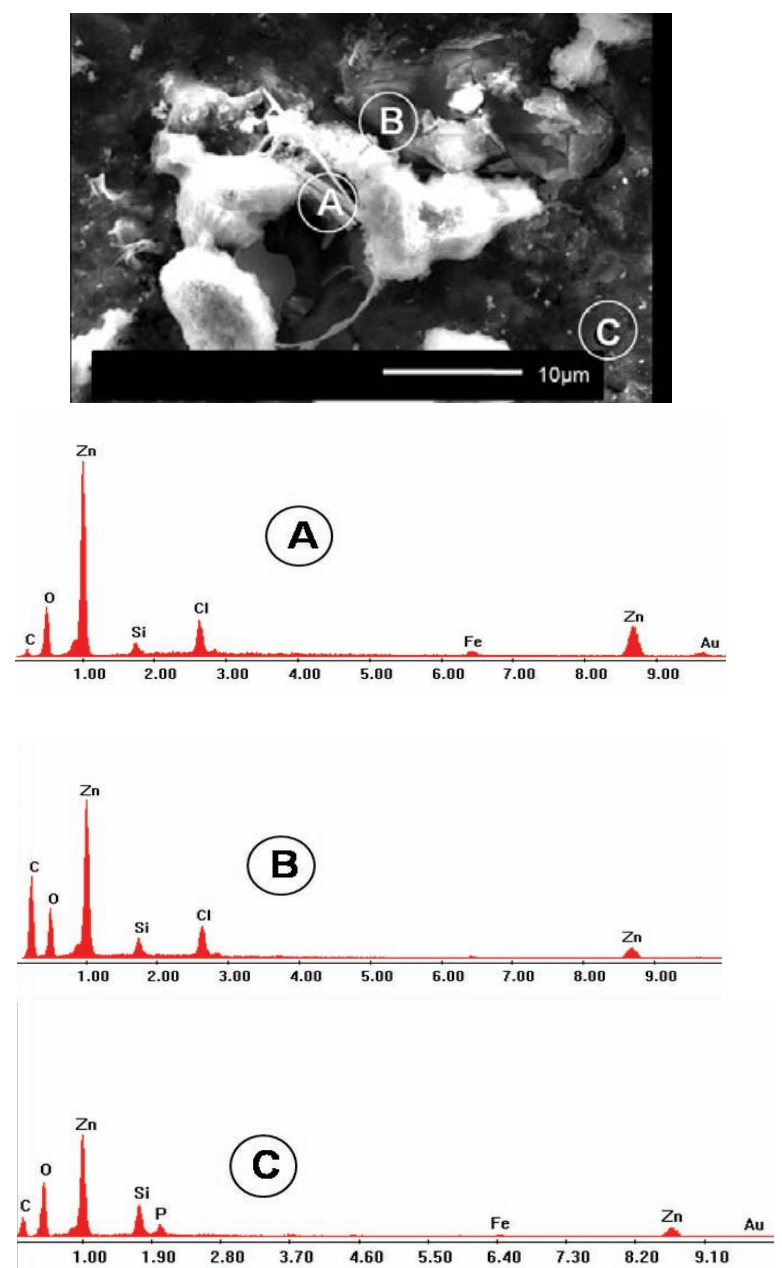

Fig. 7 - Aspects, observed by SEM, and corresponding EDS spectra of primer 2 applied on galvannealed steel after 5 cycles exposure [7]. 
On the cupping area, more or less iron corrosion was observed in all primers and substrates. Electrophoretic primer presented lower performance, with significant blister formation.

Concerning the stone chipping area, the results obtained for the three primers are similar. However, electrogalvanized and hotdip galvanized steels coated with primer 2 presented less iron corrosion than when coated with primer 1 and electrophorectic primer.

Among the three substrates, galvanneal seems to be the one that presented the best performance on the stone chipping area. Only slight iron corrosion was observed for the three primers. On the cupping area of samples coated with primer 1 and 2, the best and worst performance was presented by galvannealed steel and electrogalvanized steel, respectively.

\section{CONCLUSIONS}

Primers 1 and 2 showed formability capabilities similar to that of the electrophoretic primer. Concerning cupping test, the Erichsen indices (IE) are similar for the three primers and for the three substrates. On samples submitted to stone chipping test, it was, generally, verified similar performance of samples with electrophoretic primer and of samples with primer 2. Primer 1 presented somewhat lower performance.

For primers 1 and 2 applied on the three zinc substrates (electrogalvanized, galvannealed and hot-dip galvanized steel), after 10 corrosion cycles according to VDA procedure 621-415, the degradation on the undamaged surface and on the pie pan deformation was low, or not significant. Red corrosion was not observed on the undamaged surface. On pie pan deformation, iron corrosion appeared only for the primer 2 applied on electrogalvanized steel.

On cupping area the worst performance was presented by electrophoretic primer, with significant blisters formation.

Concerning the combination substrate/primer, on the cupping area, primers 1 and 2 presented the best and the worst performances when applied on galvannealed steel and electrogalvanized steel, respectively. On the stone chipping area, for all three primers, the best performance was observed when they had been applied on galvannnealed steel. More iron corrosion was generally verified for the primers applied on electrogalvanized steel.

On the surface of primer 1 submitted to cyclic corrosion test, thin acicular crystals and plate-like hexagonal crystal were observed by SEM. Aggregates of acicular crystals can correspond to basic zinc carbonate $\left[\mathrm{Zn}_{5}(\mathrm{OH})_{6}\left(\mathrm{CO}_{3}\right)_{2}\right]$ and plate-like hexagonal crystal to zinc hidroxychloride hydrate $\left[\mathrm{Zn}_{5}(\mathrm{OH})_{8} \mathrm{Cl}_{2} \cdot 2 \mathrm{H}_{2} \mathrm{O}\right]$. Humidity and temperatures conditions, and the relative polarizability of $\mathrm{OH}^{-}, \mathrm{CO}_{3}{ }^{2-}$ and $\mathrm{Cl}^{-}$ions, may be responsible for the mechanisms of formation of the different types of zinc corrosion products observed. Basic zinc carbonate and other zinc compounds can be replaced by increasingly dense plate-like structures of basic zinc chloride (pseudo-hexagonal crystals).

Primer 2 is a water-based primer with graphite filler and, due to its very low thickness (near $2 \mu \mathrm{m}$ ), before exposure zinc from the metallic coating substrate, was detected by EDS.

After 5 cycles exposure, it was possible to see by SEM, zinc corrosion products on the surface of primer 2 arising from the pores of the paint coating, in the form of acicular aggregates and of plate-like hexagonal crystals. As in the case of primer 1, the major compound of acicular aggregates should be basic zinc carbonate (hidrozincite) and the plate-like hexagonal crystals can correspond to zinc hidroxychloride hydrate.
The primer 2, with a very low thickness, acts as a sealer of metallic zinc coatings, not allowing the zinc "exhaustion", and delaying the appearance of iron corrosion from the steel substrate.

Primers 1 and 2 applied with low thickness, showed to be good alternatives to the conventional electrophoretic primer system. According to SEM studies, they offer cathodic protection when exposed, however by different manners, and added to this they allow previous welding works.

\section{ACKNOWLEDGMENTS}

The authors are grateful to Henkel Surface Technologies for their processing of the pre-primed panels. This project was sponsored by the Galvanized Autobody Partnership, a program of ILZRO.

\section{REFERENCES}

[1] M. JITSUKAWA and M. YAMASHITA, NKK Technical Review, 58-72 (2003).

[2] R. WOODALL (The Evolution of FrameCoat ${ }^{\mathrm{TM}}$ Electrocoat), 8/3/2004, http://www.pfonline.com/articles/ec0203.html.

[3] F. GOODWIN and D. SANTOS (Effect of lubrication and comparative formability performance of pre-primed coated automotive sheet steels) in Proceedings of Galvanized Steel Sheet Forum, May, Düsseldorf, Germany (2006).

[4] ISO 2808 (Paints and varnishes - Determination of film thickness), ISO, Geneve, Switzerland (1997).

[5] EN ISO 1520 (Paints and varnishes - Cupping test), CEN, Brussels, Belgium (1995).

[6] ASTM D3170 (Standard Test Method for Chipping Resistance of Coatings), American Society for Testing and Materials, Philadelphia, USA (1996).

[7] VDA 621-415 (Testing of Corrosion Protection of Vehicle Paint by Alternating Cycles Test), VDA, Frankfurt, Germany (1982).

[8] SEP 1160 (Evaluation of Weldable Corrosion Protection Primers for the Automotive Industry. Part 1: Corrosion Performance), Stahlinstitut VDEh, Düsseldorf, Germany (2004).

[9] ASTM B117 (Standard Practice for Operating Salt Spray (Fog) Apparatus), American Society for Testing and Materials, Philadelphia, USA (2003).

[10] DIN 50014 (Climates and their technical application; standard atmospheres), DIN, Berlin, Germany (1985).

[11] SAE J2334 (Cosmetic Corrosion Lab Test), SAE International, Philadelphia, USA (1998).

[12] EN ISO 4628-2 (Paints and varnishes. Evaluation of degradation of coatings. Designation of quantity and size of defects, and of intensity of uniform changes in appearance - Part 2: Assessment of degree of blistering), CEN, Brussels, Belgium (2003).

[13] E. AlmeidA, D. PEREIRA and O. FIGUEIREDO, Prog. Org. Coat., 17, 175 (1989).

[14] J. VAN EIJNSBERGEN (The Zinc Patina), Stichting Doelmating Verzinken, Holland (1972).

[15] U. R. EVANS (The Corrosion and Oxidation of Metals), Edward Arnold Publisher, Ltd., London, UK (1960).

[16] J. GONZALEZ and J. BASTIDAS, Rev. Iber. Corros. Prot., 13, 7 (1982). 